\title{
Research on mechanical properties of C30 Model Steel Fiber
}

\section{Reinforced Rubber Concrete}

\author{
1,a Zhide Huang, ${ }^{2,} \mathrm{~b}^{*}$ Mowen Xie, ${ }^{3}$ Zhenyu Xiang \\ ${ }^{1}$ The Scool of Civil and Environmental Engineering, The University of Science and Technology \\ Beijing, Beijing 100083, China \\ ${ }^{2}$ Beijing 100083Beijing Building Energy Conservation and Building Materials Management Office \\ Building 3, Beijing, 100039, China \\ ahuangzhd-211@163.com, ${ }^{b}$ mowenxie@126.com,
}

Key Words: Model steel fiber, Compressive strength, Flexural strength, Static elastic modulus

\begin{abstract}
As a new type of modified fiber, model steel fiber has both the appearance and function of steel fiber and the advantages of synthetic fiber. In order to make up for the mechanical properties of rubber concrete, the basic mechanical properties of C30 model steel fiber content reinforced rubber concrete, including compressive strength, splitting tensile strength, flexural strength, and static elastic modulus were studied. The results show that: the rubber particles decrease concrete strength, and the lower rate of compressive strength is greater than the bending and splitting tensile strength, but the toughness of concrete is enhanced. The 6-18mesh with10\% vol. was chosen. The model steel fiber changed the damage state of rubber concrete, producing only micro cracks in the compressive, splitting tensile and flexural failure. When the model steel fiber content is $8 \mathrm{~kg} / \mathrm{m}^{3}, 28 \mathrm{~d}$ flexural strength increases by $25.8 \%$, the ratio of compressive strength to flexural strength and the static elastic modulus is reduced by $6.9 \%$ and $5.3 \%$.
\end{abstract}

\section{Introduction}

Waste tires is not easy to degrade Stacking, landfill or burning all poses serious environmental problems. Recycling is an effective way to deal with this problem. Under the background of resources starvation, environmental pollution serious, and sustainable development transformation, more and more colleges start the studies on rubber concrete. Tongji university ${ }^{[1]}$, shijiazhuang railway university ${ }^{[2]}$, southeast university ${ }^{[3]}$ and tianjin university ${ }^{[4]}$, did this research relatively more earlier. Zhu Han, the professor of tianjin university, is one of the pioneers in the field of domestic rubber concrete research. He did a lot of research on the waste rubber powder cement mortar, concrete, exterior wall coating, etc. Existing research shows that grinding waste tires into granular or powder, and then adding them into concrete or mortar, can reduce environmental pollution, while improve the brittleness and heat preservation insulation properties of concrete or mortar ${ }^{[5]}$. But the bond interface of rubber and cement is weak, causing concrete strength to decline dramatically. Adding fiber materials is one of the effective measures to improve the utilization rate of rubber in the concrete.

Model steel fiber is one of crude fiber with rough surface and exterior chiseled monofilament, which is modified from polypropylene polymer through special process technology. Model steel fiber has both the shapes and function of steel fiber, and the advantages of synthetic fiber. The present domestic research on model steel fiber reinforced concrete is less. the basic mechanical 
properties including compressive strength, splitting tensile strength, bending strength, and static compressive elastic modulus of rubber particle and model steel fiber reinforced concrete were studied in this article, considering different rubber particle contents, size, and model steel fiber contents.

\section{Raw materials and test methods}

Raw materials

1) Cement, P.O42.5, Produced in Inner Mongolia wuhai city cement business co., LTD.;2) Medium sand, taken from a site in the city, fineness modulus of 2.63 , silt content of $14.6 \%$, apparent density of $2650 \mathrm{~kg} / \mathrm{m}^{3}$, bulk density of $1520 \mathrm{~kg} / \mathrm{m}^{3}$; 3) Gravel, apparent density of $2800 \mathrm{Kg} / \mathrm{m}^{3}$, stacking density of $1524 \mathrm{Kg} / \mathrm{m}^{3}$, porosity of $45.57 \%$, moisture content of $18.8 \%, 5-20 \mathrm{~mm}$ continuous gradation; 4) Rubber particle, fineness for 5-10 mesh, 6-18 mesh, 40-60mesh, bulk density of 630.1 $\mathrm{Kg} / \mathrm{m}^{3}, 660 \mathrm{Kg} / \mathrm{m}^{3}$ and $\left.406 \mathrm{Kg} / \mathrm{m}^{3} ; 5\right)$ Commercially available model steel fiber , length of 30-40 $\mathrm{mm}$; 6) Ordinary tap water.

Test methods

The experiments were did according to $<$ Standard for test method of performance on ordinary fresh concrete > (GB/T50080-2002), and < Standard for test method of mechanical properties on ordinary concrete> (GB/T50081-2002).

Mix proportion

According to <Specification for mix proportion design of ordinary concrete> (JGJ 55-2011), the design target was $\mathrm{C} 30$; the sand ratio was $41 \%$; water to cement ratio was 0.41 ; the volume contents of rubber particles was $2 \%, 5 \%, 10 \%, 15 \%, 20 \%$ and $25 \%$,replacing of sand with the same volumes; and the model steel fiber was put into the concrete with $2 \mathrm{~kg} / \mathrm{m}^{3}, 4 \mathrm{~kg} / \mathrm{m}^{3}, 6 \mathrm{~kg} / \mathrm{m}^{3}, 8 \mathrm{~kg} / \mathrm{m}^{3}, 10$ $\mathrm{kg} / \mathrm{m}^{3}$. the fluidity of concrete was controlled for $160 \pm 20 \mathrm{~mm}$, and the water reducing agent could be mobilized in small range. Mix proportion was shown in Table 1.

Table1 Mix proportion of concrete

\begin{tabular}{ccccccc}
\hline $\begin{array}{c}\text { Cement } \\
\left(\mathrm{Kg} / \mathrm{m}^{3}\right)\end{array}$ & $\begin{array}{c}\text { Fly ash } \\
\left(\mathrm{Kg} / \mathrm{m}^{3}\right)\end{array}$ & $\begin{array}{c}\text { Slag } \\
\left(\mathrm{Kg} / \mathrm{m}^{3}\right)\end{array}$ & $\begin{array}{c}\text { Water } \\
\left(\mathrm{Kg} / \mathrm{m}^{3}\right)\end{array}$ & $\begin{array}{c}\text { Sand } \\
\left(\mathrm{Kg} / \mathrm{m}^{3}\right)\end{array}$ & $\begin{array}{c}\text { Gravel } \\
\left(\mathrm{Kg} / \mathrm{m}^{3}\right)\end{array}$ & $\begin{array}{c}\text { Water reducing } \\
\text { agent }\end{array}$ \\
\hline 280 & 40 & 80 & 165 & 750 & 1080 & 12 \\
\hline
\end{tabular}

\section{The influence of rubber particle fineness on mechanics properties of concrete}

Rubber particle size is marked in mesh. The bigger mesh indicates the smaller of the particle size. Use rubber particles instead of sand by $10 \%$ volume, the influence of rubber particles mesh on the basic mechanical properties of concrete ia shown in Table 2, with $10 \%$ rubber particles contents.

Table 2 The mechanical properties of concrete with different mesh rubber particles

\begin{tabular}{cccccc}
\hline Mesh & $\begin{array}{c}\text { 28d Cube } \\
\text { compressive,MPa }\end{array}$ & $\begin{array}{c}\text { 28d Axial } \\
\text { compressive, } \\
\mathrm{MPa}\end{array}$ & $\begin{array}{c}\text { 28d Flexural } \\
\text { strength,MPa }\end{array}$ & $\begin{array}{c}\text { 28d tensile } \\
\text { splitting,MPa }\end{array}$ & $\begin{array}{c}\text { Elasticity } \\
\text { modulus } \\
\mathrm{GPa}\end{array}$ \\
\hline $\mathrm{J}$ & 40.1 & 38.6 & 3.57 & 2.53 & 35.2 \\
$5-10$ & 39.6 & 39.1 & 3.28 & 2.91 & 28.2 \\
$6-18$ & 34.6 & 36.4 & 4.44 & 2.72 & 26.2 \\
$40-60$ & 35.4 & 36.6 & 3.49 & 2.82 & 25.7 \\
\hline
\end{tabular}


Table 2 shows that, the addition of rubber particles makes the cube and axial compressive strength of concrete reducing. With the increase of rubber particle mesh, the reduction of concrete compressive strength increase, which is due to the rubber is organic polymer materials and the bond surface of rubber and cement based materials is weak. The reduction rate of $28 \mathrm{~d}$ cube compressive strength is greater than the axial compressive strength, and the ratio of axial compressive strength and cubic compressive strength is increasing, this is because the toughness of rubber can weaken the hoop effect of cube compressive strength.

\section{The influence of rubber particle contents on mechanics properties of concrete}

The rubber 6-18 mesh of rubber particle size is chosen, and the rubber particle contents are 2\%, 5\%, $10 \%, 15 \%, 20 \%, 15 \%$. In the design of experiment, (rubber particles + sand)/aggregate is equal to the original sand ratio. with the content increasing of rubber particles, the fluidity of concrete decrease, and the bulk density decrease, which is associated with water absorption and expansion characteristics of rubber particles. The influence of rubber particles contents on the mechanical properties of concrete was shown in Table 3.

Table 3 The mechanical properties of concrete with different rubber particle content

\begin{tabular}{ccccccc}
\hline Mesh & $\begin{array}{c}\text { 28d Cube } \\
\text { compressive,MPa }\end{array}$ & $\begin{array}{c}\text { 28d Axial } \\
\text { compressive, } \\
\mathrm{MPa}\end{array}$ & $\begin{array}{c}\text { 28d Flexural } \\
\text { strength,MPa }\end{array}$ & $\begin{array}{c}28 \mathrm{~d} \\
\text { tensile } \\
\text { splitting } \\
\mathrm{MPa}\end{array}$ & $\begin{array}{c}\text { Elasticity } \\
\text { modulus } \\
\mathrm{GPa}\end{array}$ \\
\hline 0 & 40.1 & 38.6 & 3.57 & 2.53 & 11.2 & 0.96 \\
2 & 43.5 & 42.6 & 4.58 & 2.81 & 9.5 & 0.98 \\
5 & 40.8 & 38.7 & 4.23 & 2.45 & 9.6 & 0.95 \\
10 & 34.6 & 36.4 & 4.49 & 2.69 & 7.8 & 1.05 \\
15 & 35.8 & 31.4 & 4.09 & 2.79 & 8.7 & 0.88 \\
20 & 34.8 & 30.3 & 4.07 & 2.32 & 8.5 & 0.87 \\
25 & 29.6 & 28.5 & 3.57 & 1.91 & 8.3 & 0.96 \\
\hline
\end{tabular}

Table 3 shows that when the rubber particles content is $2 \%$, the concrete strength increase, because of the dense skeleton effect of rubber particles which can weaken the interface negative influences. When the content of rubber particles is more than $2 \%$, with the increase of content, the strength gradually reduce, and the lower rate of compressive strength is greater than the flexural and splitting tensile strength. The flexural strength were higher than reference concrete, when the rubber particles content is less than $25 \%$. The swell and air-entraining feature of rubber particles make concrete compressive strength reduce, especially when the content is more than $10 \%$. The toughness of concrete is enhanced, because of tensile toughness of rubber, which can be vertified by the ratio of compressive strength to flexural strength and the static elastic modulus value.

\section{The influence of model steel fiber contents on mechanical properties of rubber concrete}

As toughness material, model steel fiber can make up for the negative effect of rubber particles. In order to produce model steel fiber rubber concrete, 6-18 mesh rubber particles was selected, and the rubber particle contents is $10 \%$, then the model steel fiber was chosen with the length of $30-40 \mathrm{~mm}$. the contents range of model steel fiber is $2 \mathrm{~kg} / \mathrm{m}^{3}, 4 \mathrm{~kg} / \mathrm{m}^{3}, 6 \mathrm{~kg} / \mathrm{m}^{3}$, and $8 \mathrm{~kg} / \mathrm{m}^{3}$. The influence of model steel fiber contents on basic mechanical properties of rubber concrete is shown in Table4. Table 4 shows that with the increase of model steel fiber contents, the $28 \mathrm{~d}$ cube compressive strength and axial compressive strength of rubber concrete first increases and then decreases, 
reaching the peak point in the dosage of $4 \mathrm{~kg} / \mathrm{m}^{3}$ and $6 \mathrm{~kg} / \mathrm{m}^{3}$ respectively. The main reason for strength increasing is the model steel fiber inhibitory effect on the development of cracks. With the increase of model steel fiber contents, the phenomenon of non-uniform distribution are appeared, which plays a negative role in the process of compression. The bigger the model steel fiber contents, the weakness is greater. Table 4 also shows that the flexural strength of rubber concrete increase with the model steel fiber contents increase. When the plastic fiber content is $8 \mathrm{~kg} / \mathrm{m}^{3}$, the $28 \mathrm{~d}$ flexural strength increases by $25.8 \%$, and the ratio of compressive strength to flexural strength and the static elastic modulus was reduced by $6.9 \%$ and $5.3 \%$ respectively. The ratio of axial compressive strength to cube compressive strength is increased too, because of the formation of model steel fiber enhanced network. In the process of experiments, the splitting tensile strength remains unchanged, only increase a little when the in the model steel fiber content is higher.

Table4 the influence of model steel fiber contents on rubber concrete mechanical properties

\begin{tabular}{ccccccc}
\hline $\begin{array}{c}\text { Fiber } \\
\begin{array}{c}\text { contents } \\
\mathrm{kg} / \mathrm{m}^{3}\end{array}\end{array}$ & $\begin{array}{c}\text { 28d Cube } \\
\text { compressive,MPa }\end{array}$ & $\begin{array}{c}\text { 28d Axial } \\
\text { compressive } \\
\mathrm{MPa}\end{array}$ & $\begin{array}{c}\text { 28d Flexural } \\
\text { strength,MPa }\end{array}$ & $\begin{array}{c}\text { 28d } \\
\text { tensile } \\
\text { splitting } \\
\mathrm{MPa}\end{array}$ & $\mathrm{C} / \mathrm{F}$ & $\begin{array}{c}\text { Elasticity } \\
\text { modulus } \\
\mathrm{GPa}\end{array}$ \\
\hline 0 & 35.0 & 33.3 & 4.49 & 2.69 & 7.8 & 26.2 \\
2 & 37.4 & 34.8 & 3.67 & 2.72 & 10.2 & 25.5 \\
4 & 37.4 & 37.1 & 4.19 & 2.61 & 8.9 & 27.0 \\
6 & 39.5 & 36.4 & 4.33 & 2.68 & 9.1 & 27.5 \\
8 & 38.2 & 34.3 & 5.65 & 2.75 & 6.8 & 24.8 \\
\hline
\end{tabular}

\section{Conclusion}

1) The smaller the rubber particles size is, the faster the compressive strength of concrete is decreased. According to the flexural strength, the ratio of compressive strength to flexural strength and the static elastic modulus, shows the rubber particles of 6-18 mesh is chosen. When the rubber particle content is more than $2 \%$, the mechanical properties of rubber concrete is gradually reduced, and the lower rate of compressive strength is greater than the flexural and splitting tensile strength, but the concrete toughness is enhanced. The rubber contents should be less than $15 \%$.

2) The addition of model steel fiber makes the $28 \mathrm{~d}$ cube compressive strength and axial compressive strength of rubber concrete first increases and then decreases. When the fiber contents are $8 \mathrm{~kg} / \mathrm{m}^{3}$, the $28 \mathrm{~d}$ flexural strength increases by $25.8 \%$, and the ratio of compressive strength to flexural strength and the static elastic modulus decreased by $6.9 \%$ and $5.3 \%$ respectively. The appropriate content of model steel fiber is $8 \mathrm{~kg} / \mathrm{m}^{3}$.

\section{Reference}

[1] Jie Xiong, Lei Zheng, Yong Yuan. Experimental study on compressive strength of rubberized concrete [J].concrete,2004,(12):40-42(In chinese)

[2] Shaomin Song, Juanhong Liu, shuxin Jin. Rubber powder modified high toughness of the concrete research [J] Concrete and cement products, 1997,(1):10-11,53(In chinese)

[3] Bo Chen, Yamei Zhang, Shengxia Chen, Caihua Zhang. Fundamental research of properties of rubberized concretes [J].concrete,2004, ( 12 ) :37-39(In chinese)

[4] Zhu Han. New elastic concrete research summarize [J].Tianjin Construction Science and 
Technology,2004,(2):35-37(In chinese)

[5] Segre N, Joekes I. Use of tire rubber particles as addition to cement paste[J].Cement and Concrete Research,2000,30:1421-1425 